\title{
Anticorruption personality orientation as an innovative component of teaching of cadets of educational organizations of the Federal Penal Service of Russia
}

Irina Ganishina, Larisa Fedoseeva, Juri Vorobyev, and Viktoria Sundukova*

Academy of Law and Management of the Federal Penal Service of Russia, Ryazan, the Russian Federation

\begin{abstract}
Fight against corruption is one of global problems of modern society, that is why law-enforcement agencies have the most important objective of developing effective and innovative psychological and educational technologies of fighting against corruption-related offences. It is especially important to form rejection of corruption by would-be lawenforcement officials (specialists of the Ministry of Internal Affairs, the Federal Security Service, the Federal Penal Service, the Investigation Committee, the Judicial System, the Prosecutor's Office), as life and health of the population of Russia depends on the legitimacy of their decisions. One of the ways to fight against corruption in organizations of higher education can be forming of students' anticorruption personality orientation which is realized by the authors as integrative personality education providing anticorruption legislation compliance in the sphere of professional occupation by means of structural components of personality orientation (motivationalaxiological, emotional-volitional, cognitive, spiritual and moral) which are being formed in the process of studying in the higher education establishment.
\end{abstract}

\section{Introduction}

Modern statistics shows that there is an increase of corruption-related offences in Russia. In 2018, the number of such offences was rather big and equaled to 3171 (in 2017-2251) which leads to the raise of number of corruption convicts. According to this, theissuesofimprovingofmeansoffightagainstcorruptioninthelaw-enforcementsystem, including the officials of the penal enforcement system (thereinafter "PES"), are relevant.

In the conditions of modern Russia, innovative technologies are required in the process of training of specialists for law-enforcement agencies. These technologies should be able to prepare specialists to possible corrupt practices. For the purpose of psychological prophylactic of anticorruption behavior of would-be specialists of the PES, an authorial programme on forming of anticorruption orientation of military students of higher

\footnotetext{
* Corresponding author: vika.sundukova94@mail.ru
} 
educational establishments of the Federal Penal Service of Russia has been developed [21]. The aim of this programme is to develop cadets' resistance to corruptogenic situations. This programme consisted of four functional sections: diagnostic, prophylactic, psychocorrective and the section of evaluation of programme efficiency. The efficiency of the programme was evaluated during the repeated psychodiagnostic research and comparison of the results of measuring of individual-psychological characteristic features of the forming of structural components of anticorruption personality orientation.

Research methods and techniques: observation, interlocution, testing, 16factorspersonalityquestionnaire

(R.B. Cattell), diagnostics of the real structure of axiological personality orientations (S.S. Bubnov), diagnostics of social-psychological personality attitudes in the motivational-need sphere (O.F. Potyomkina), the personality questionnaire of moral-legal reliance (E.Yu. Strizhov), the strategic approach to coping scale (S. Hobfoll), educational experiment, methods of mathematical statistics (correlation analysis).

The aim of the research is to form and evaluate the anticorruption personality orientation of the cadets of educational organizations of the Federal Penal Service of Russia.

The scientific novelty of the research lies in the development and approbation of a technology of forming anticorruption personality orientation of the cadets of educational organizations of the Federal Penal Service of Russia. As a technology of forming of anticorruption orientation we take an authorial programme "Forming of anticorruption orientation of cadets of educational organizations of the Federal Penal Service of Russia programme".

\section{The theoretical framework for the study}

In modern psychology, S.L. Rubenstein (1964) was the first who introduced the notion "personality orientation" by which he meant the complex of different tendencies which have personality needs and motives as their basis [19]. Russian scientists agree that the personality orientation is the leading component of its structure. The orientation as a personality substructure is formed in the process of training and education, in the process of direct professional learning and learning of skills of community service. Such scientists as S.L. Rubenstein (1946) [19], V.N. Myasishchev (1965) [15], A.N. Leontyev (1975) [12], H.F. Dobrynin (1976) [7], B.I Dodonov (1978) [8], V.S Merlin (1986) [14],. B.F. Lomov (1984) [13], K.K. Platonov (1986) [17] contributed much in the study of this issue. The analysis of scientific approaches to the personality orientation has shown that it is evolutionizing under the influence of the formed structure of attitudes and conditions where the process of personality formation takes place. The personality orientation represents a feature of a human being's psyche which stimulates and regulates a conscious activity of a human being. The personality orientation is defined not only by the motives of an activity, but also its attitude to different sides of social life. According to S.L. Rubenstein (1964), the orientation represents an integrating feature of personality where personality needs and interests appear from changing and evolutionizing relationships between a human being and the world around [19].

The issue of fight against corruption was elaborated by M.M. Reshetnikov (2008) [18], O.V. Vannovskaya (2009) [3], A.V. Yuryevitch (2009) [9], R.R. Garifullin (2012) [6], A.R. Ratinova (2015) [11], M.V. Kroz $(2018,2019)$ [11] and others. The analysis of scientific works on the research of anticorruption constituent of personality has shown that an ability to resist corruption is considered by a lot of educators and psychologists as a quality formed in the process of teaching and education. Thisopinion is supported by T.M. Bezubyak (2010)
[1],
E.S.
Budagov
(2012)
[2], 
V.A. Petchyonkin (2012) [16], A.R. Khamdeev (2015) [22], D.A. Rybalkin (2015) [20], E.A. Sharapova (2016) [23], V.V. Kiselyov (2016) [10] and others.
According
to
most
scientists,

thesystematicallyimportantcomponentsofthepersonalityorientationarethefollowing: an emotional-volitional

component

(subjectiveattitudetodifferentsidesofrealityaccompaniedbyanemotionalresponse);

a

motivational-axiological component (active purposive activity pushed by personal needs and motives, aims, interests and instincts); a cognitive component (beliefs and reportable needs and personality interests in relationships between a human being and the surrounding reality); a spiritual and moral component (a view of life of a personality)[5]

A variety of theoretical approaches to the content of the notion "personality orientation" proves the actuality of study of this phenomenon, as the orientation itself coordinates a human being's activity. Structural components of the orientation are fixed in cultural, social and professional spheres of life which provides structural completeness and complexity of the range of personality manifestations. They help to develop such kind of personality which could correspond to modern realia of the society, including corruption. That is why in educational organizations of the Federal Penalty Service of Russia, an important stage of professional development of cadets is forming of the anticorruption personality orientation [4]. The anticorruption personality orientation represents personality resistance to different signs of corruption behavior which provides the compliance o requirements of the criminal legislation by means of formation of structural components of personality orientation (motivational-axiological, emotional, volitional, cognitive, spiritual and moral).

\section{The analysis of empirical and experimental research}

We used the programme of forming of the anticorruption personality orientation of cadets of educational organizations of the Federal Penal System of Russia in terms of conducting an educational experiment and execute the problem longitudinally. The programme included four consecutive stages: diagnostic, prophylactic, psychocorrective and the section of evaluation of programme efficiency. For the educational experiment, we chose 2 random groups of cadets (control and experimental). According to the rules of a psychological experiment, the experimental group got the educational impact, while the control group was used for comparison.

The research of peculiarities of formation of the anticorruption personality orientation was executed in 2018 by means of the psychodiagnostic section. The primary diagnostics of the maturity of structural components of anticorruption personality orientation was executed among the cadets of the first year of studying by means of the set of psychodiagnostic methods and techniques: observation, interlocution, testing, 16-factors personality questionnaire

(R.B. Cattell), diagnostics of the real structure of axiological personality orientations (S.S. Bubnov), diagnostics of social-psychological personality attitudes in the motivational-need sphere (O.F. Potyomkina), the personality questionnaire of moral-legal reliance (E.Yu. Strizhov), the strategic approach to coping scale (S. Hobfoll), educational experiment, methods of mathematical statistics (correlation analysis).

The objective of the prophylactic stage was the conducting of educational events aimed at the development of structural components of anticorruption personality orientation. As for the main forms of activities of the prophylactic stage, they were educational work with cadets through individual interlocutions, counseling sessions, lectures and seminars, round-table discussions on the issues of fight against corruption, the contest of posters and wall newspapers on the issues of the fight against corruption, meetings with representatives of the 
executive power and prosecutor's office on the purpose of presenting statistics data about corruption offences.

The psychocorrective stage presupposed the use of psychological technologies, techniques and methods of impact on personality on the purpose of forming of resistance to situations of corruption risk. For psychocorrective work with cadets who had a low level of maturity of indexes of structural components of the anticorruption personality orientation, we used the following psychocorrective exercises: art-therapy, movie-therapy, trainings and group discussions.

We evaluated the effectiveness of the program in 2019 at the repeated psychodiagnostic testing among the cadets of the second year of education and comparing the results of measuring of individual psychological peculiarities characterizing the level of maturity of structural components of the anticorruption personality orientation.

We shall consider the most important conclusions of the analysis of the executed empiric and experimental research.

The analysis of the results of the empiric research according to the technique "16-factor personality questionnaire by R.B. Cattell" has shown that we have got high indexes at the scale " $C$-emotional resistance/non-resistance" and " $H$ - shyness/courage". This proves the maturity of the first-year cadets' enterprising, activeness, readiness to risk, ability to make independent, non-ordinary decisions, tendency to adventurism and showing leadership qualities, ability to manage their psychoemotional state, be moderate, fit to work and make considered decisions. The indexes at the scale " $\mathrm{C}$-emotional resistance/non-resistance" prove that the cadets possess personality maturity, ability to manage their emotions and feelings sufficiently in their relationships with others. In the personality profile of the firstyear cadets, we can highlight such significant features as high order of intelligence, emotional stability, dominancy, expressiveness, courage, suspicion, dreaminess, diplomacy, anxiety, nonconformity, tension and inflated self-assessment. There is also middle intensity of sociability, standardized behavior, sensitivity, radicalism, self-control. The results shown prove that the cadets have an inner conflict: on the one hand, they show emotional control and stability, significant leadership qualities, independence, readiness to risk, but on the other hand - a distinctive sign of anxiety, impulsivity, sensitivity to social approval of people around and their critical remarks. In our opinion, detected psychological peculiarities of the first-year cadets are determined by the process of active personality development as well as their adaptation to the conditions of studying in educational organizations of the Federal Penalty Service of Russia.

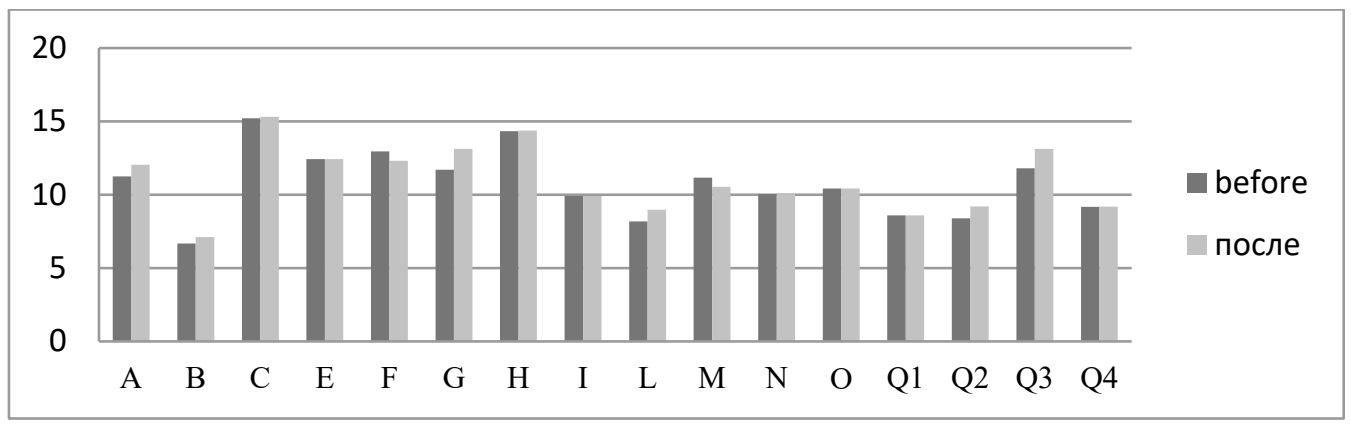

Fig 1. Average indexes according to the results of the research of cadets according to the technique of "16-factor personality questionnaire by R.B. Cattell"

Explanatory note. A (- disengagement - kindness +$)$, B ( - low intelligence - high intelligence +$), \mathrm{C}(-$ emotional resistance - emotional non-resistance), E (- dependency - dominancy +$)$, F (- concern - 
carelessness +), G (- weakness of "SuperEgo" - strength of "SuperEgo" +), H (-shyness -courage+), I ( - violence-soft-heartedness +$),$ L ( - nonconformity - conformity +$),$ M (-practicality daydreaming +$)$, O (- self-confidence - modesty +$)$, Q1 (- radicalism - conservatism +$)$, Q2 (dependency- self-sufficiency +$)$, Q3 (- impulsivity - desire-control +), Q4 (- non-frustration frustration + ).

The comparative analysis of the results of the educational experiment before and after the application of psychological and pedagogical programme has shown that we can see increase of average indexes of the second-year cadets at the scales A - disengagement/kindness, B high/low intelligence, C - emotional resistance/non-resistance, Q2 - dependency/selfsufficiency, Q3 - low/high level of self-control, G - negligence/tenderness, H shyness/courage, I - violence/soft-heartedness, and decrease of indexes at the scale F concern/carelessness. The results that we got show that, after the use of the psychological and pedagogical programme, the second-year cadets have increased their level of self-control of emotions and behavior, have gained self-confidence in establishing interpersonal contacts, have developed constructiveness in building relationships with others, have gained an ability to behave adequately depending on the conditions of the reality around, have formed a particular hierarchy of motives, have developed a moderate seeking for better advocating of their views and principles, have gained a desire to achieve goals and show persistence. After the conducted psychological and pedagogical experiment in terms of using the authorial programme, the level of emotional tension and impulsivity decreased, the level of working efficiency increased. This fact shows the maturity of the emotional-volitional component of the anticorruption orientation of the second-year cadets of educational organizations of the Federal Penalty Service of Russia.

\section{Conclusion}

Comparative analysis of the educational experiment among the first- and second-year cadets has shown that the developed authorial programme of forming the anticorruption orientation of the cadets of educational organizations of the Federal Penal System of Russia is effective. This fact presupposes its use in the educational process of the higher educational establishment as an innovative educational technology.

\section{References}

1. T.M Bezubyak, Chelovek i obrazovanie, 3, 66-69 (2010)

2. E.S Budagov, Psikhologo-pravovye mekhanizmy formirovaniya antikorruptsionnoi kompetentnosti sotrudnikov UVD (2012)

3. O.V Vannovskaya, Vestn. Mosk. gos. oblastn. un-ta. - Ser. «Psikhologicheskie nauki». 3, (2011)

4. I.S Ganishina, V.V Sundukova, Perspektivy nauki, 7, (2019)

5. I.S Ganishina, V.V Sundukova, Formirovanie antikorruptsionnoi i antinarkoticheskoi napravlennosti lichnosti kursantov obrazovatel'nykh organizatsii FSIN Rossii (2019)

6. R.R Garufillin, Psikhologicheskie i psikhoterapevticheskie podkhody k probleme vzyatochnichestva i vzyatkomanii (novaya kontseptsiya resheniya problemy korruptsii) (2011)

7. N.F Dobrynin, Vnimanie (1976)

8. B.I Dodonov, Emotsiya kak tsennost' (1978)

9. A.L Zhuravlyov, A.A Yurevitch, Psikhologiya v ekonomike i upravlenii. 1, 57-66 (2012) 
10. V.V Kiselyov, Psikhologicheskie determinanty antikorruptsionnogo povedeniya sotrudnikov gosudarstvennoi organizatsii (2016)

11. M.V. Kroz, N.A Ratinova, Vestn. Akad. Gen. prokuratury Ros. Federatsii, 6, (2016)

12. A.N Leontyev, Deyatel'nost', soznanie, lichnost' (1975)

13. B.F Lomov, Napravlennost' lichnosti. Sub"ektivnye otnosheniya lichnosti (2000)

14. V.S. Merlin, Ocherk integral'nogo issledovaniya individual'nosti (1986)

15. V.N Myasishchev, O vzaimosvyazi obshcheniya, otnosheniya i otrazheniya, kak probleme obshchei i spetsial'noi psikhologii (1970)

16. V.A Petchyonkin, Formirovanie antikorruptsionnoi kompetentnosti gosudarstvennykh sluzhashchikh (2012)

17. K.K. Platonov, Struktura i razvitie lichnosti (1986)

18. M.M Reshetnikov, Psikhologiya korruptsii: utopiya i antiutopii (2008)

19. S.L Rubenstein, Osnovy obshchei psikhologii (2001)

20. D.A Rybalkin, Formirovanie antikorruptsionnoi pozitsii kursantov VUZov MVD Rossii sredstvami sotsial'no-kul'turnoi deyatel'nosti (2015)

21. V.V Sundukova, Programma po formirovaniyu antikorruptsionnoi napravlennosti lichnosti kursantov obrazovatel'nykh oganizatsii FSIN Rossii (2019)

22. A.R Khamleev, A.R. Khamdeev, Pedagogicheskoe obespechenie formirovaniya antikorruptsionnoi kul'tury studentov VUZa (2015)

23. E.A Sharapova, Formirovanie antikorruppioinoi kompetentnosti studentov $\mathrm{v}$ obrazovatel'nom prostranstve sovremennogo vuza (2016) 